مجلة جامعة سبها للعلوم البحتة والتطبيقية

Sebha University Journal of Pure \& Applied Sciences

Journal homepage: www.sebhau.edu.ly/journal/index.php/jopas

\title{
Cystic Echinococcosis in Slaughtered Animals in Libya: A Review
}

*Rugaia M. A. El-Salem ${ }^{1}$, Abdulhafeez Khan ${ }^{2}$ and Eman Z Younis ${ }^{2}$

${ }^{1}$ Department of Biology, Faculty of Science, Sebha University, Libya

${ }^{2}$ Department of Biology, Faculty of Education-Ghemines, University of Benghazi, Benghazi, Libya

\section{Keywords:}

El-Salem

Cystic Echinococcosis

Slaughtered

University Sebha

\begin{abstract}
A B S T R A C T
Unilocular Cystic Echinococcosis (CE), in livestock is caused by the larval cystic stage of Echinococcus granulosus. Hydatid cysts in domestic animals lead to protein and economic losses, because of the condemnation of slaughtered animals infected viscera as well as reducing the quality and quantity of the livestock other productions such as milk, wool and meat. In Libya, hydatid disease infects a wide range of domestic animals (sheep, goats, cattle and camels) act as intermediate hosts E. granulosus. Prevalence of cystic hydatidosis based on available abattoirs data in livestock is hyper endemic in Libya and infection rates in all domestic slaughtered animals reached almost 50\%. Many abattoir investigations in Libya have revealed that hydatid cyst is a disease, which infect a wide range of animal species with variable rates of infection, for example, sheep (1.6 to 40\%), goats (5.6 to $70 \%$ ), cattle (2.7 to 56\%) and camels (2.7 to 48\%) in different cities of Libya. Population of stray dogs and its worm burden infection of E. granulosus, socio-economic development, socioeconomic agricultural practices, common traditional animal husbandry practices and the practices of slaughtering of domesticated animals continued the transmission of cystic hydatidosis in the various cities of Libya. Importance of echinococcosis given on human health and domestic animals industry, it is necessary to implement monitoring and control measures in this regard in Libya. This requires public health education and awareness about the dangers of the disease and its transmission and preventive routes, education on the appropriate ways of washing and disinfecting of vegetables and fruits, education on the correct ways of animal slaughtering, prevention on feeding dogs by viscera of home-slaughtered animals, prevention on direct contact by dogs faeces, enforce legislation on meat inspection and improve veterinary services in both government as well as private abattoirs in Libya.
\end{abstract}

$$
\begin{aligned}
& \text { داء المشوكات الكيسي في الحيو انات المذبوحة في ليبيا } \\
& \text { *رقية محمد عبدالقادر السالم و عبد الحفيظ خان 2 و ايمان زايد يونس2 } \\
& 1 \text { ق قسم الأحياء، جامعة سبها، ليبيا }
\end{aligned}
$$

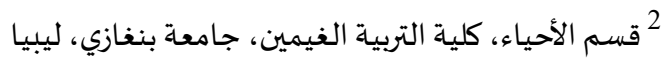

الكلمات المفتاحية: - n

السالم

داء المشوكات الكيسي

الملذبوحة

جامعة سبها

يعتبر داء المشوكات الكيسي البشري Human cystic echinococcosis الناجم عن مرحلة اليرقات من

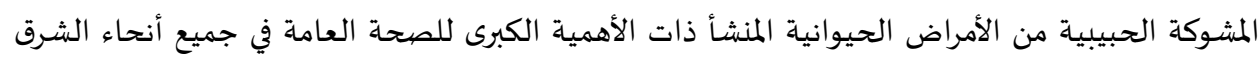

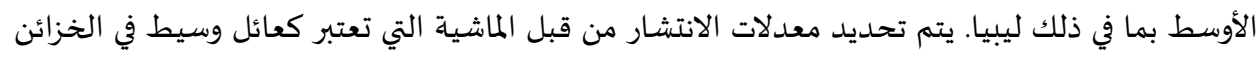

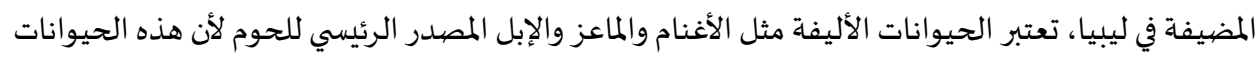

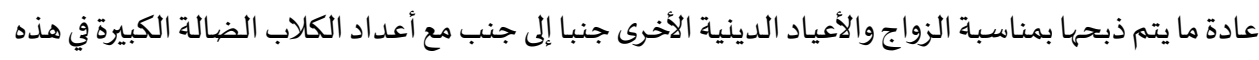

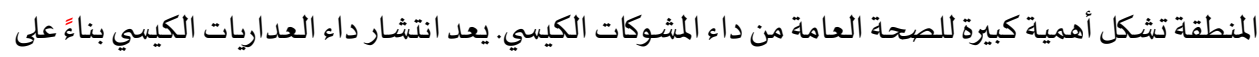

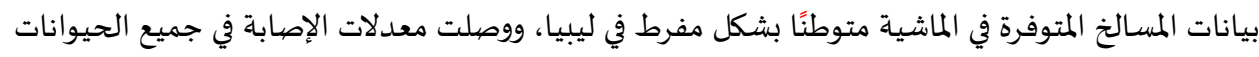

المذبوحة المنزلية إلى ما يقرب من 50٪. كشفت العديد من التحقيقات في المجازر في ليبيا أن الكيس العدارية هو

*Corresponding author:

E-mail addresses: rug.ahmed@sebhau.edu.ly, (A. Khan) abdulhafeezk@yahoo.co.uk, (E. Z. Younis) Eman.younis@uob.edu.ly Article History : Received 11 November 2020 - Received in revised form 27 April 2021 - Accepted 07 May 2021 


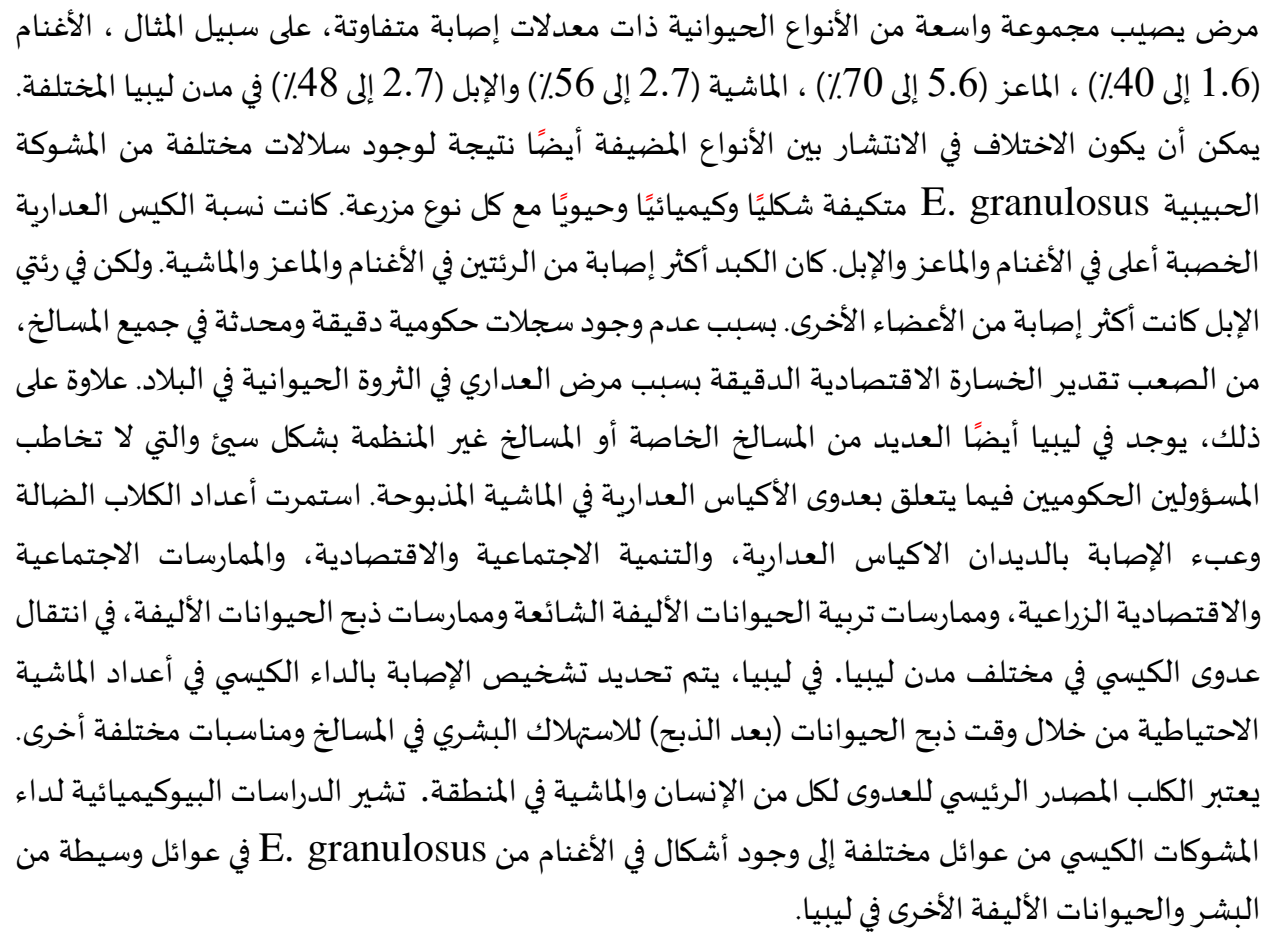

\section{Introduction}

Cystic echinococcosis or cystic hydatidosis caused by the larval stage of Echinococcus granulosus. Hydatid disease in livestock has worldwide distribution, and used to be particularly common in developing countries and under developed countries including the Mediterranean region. However, the greater prevalence of hydatid cysts is found in agricultural regions particularly in temperate zones, Central Asia, China, Australia and parts of Africa [16] [50].

Human echinococcosis in history of Arabic writing of renowned Muslim Physician Al-Razi (Circa, 900 AD), who described the nature and source of these watery sacs of dog origin as 'al-akyas al-maiyah' [1]. The traditional meat handlers and butchers often described animal hydatid cyst as 'al-atash' or thrusts because the cysts were thought to represent water remains for domestic animals (sheep, goats, cattle and camels) over long dry periods when drinking water was scare. In most of the Islamic countries, dogs are considered as 'unclean' and people in these regions do not keep them as domestic pet, with the exception of some westernized segment of society.

Human activities play also a critical role in the persistence of $\mathrm{E}$. granulosus in farm species [23]. Human behavior has also been recognized as playing a key role in the perpetuation of echinococcosis transmission [41]. This behavior is closely related to human cultural and economic backgrounds [18]. The use of epidemiological techniques and anthropologic knowledge has served in the past to highlight the reasons for the distribution of echinococcosis [7].

The wide spread of dogs population found in both urban and rural areas of Libya, which impact the endemicity of cystic echinococcosis in the region. The people often slaughter livestock on various festive and religious occasions and reward infected offal to dogs which maintain the life cycle of E. granulosus. Molecular studies of [10] in China reported the existence of a common strain of E. granulosus which infects sheep, cattle, camels, pigs, and humans. [36], [27] have also reported presence of a common homogenous strain of E. granulosus in humans and various hosts including sheep, macropods, goats, cattle, camels pigs and dingo in Australia. Quantitative similarities in the biochemical profiles of hydatid fluids in cystic echinococcosis from hosts of different origin suggest the existence of sheep forms of E. granulosus in human and other domestic animal intermediate hosts in Libya [46]. However, [9], and
[11] have described the presence of two distinct strains of E. granulosus in United Kingdom and Kenya respectively. Camels are commonly infected in the Middle East and Africa, yet opinion differs with regard to the infectivity of E. granulosus of camel origin to humans [38], [19], [49]. [39] Reported that the main causative agent for animal hydatidosis in Somalia likely to be the camel strain of E. granulosus.

Liver had higher hydatid cysts than lungs in sheep, goats and cattle, while in camel's lungs had higher infection [17], [33], [22]. The fertility of cystic echinococcosis is noticeably higher in sheep, goats and camels reinforces importance of these livestock in the endemicity and maintaining the life cycle of cystic hydatidosis in Libya [17], [24], [31], [33] and [35].

The dog is the principal source of infection for both humans and livestock for echinococcosis in the region. The ability of dogs to roam freely in the areas is the most commonly associated risk factors for the infection of E. granulosus [16] [14], [37]. Likewise, stray dogs showed greater intensity of infection compared with domesticated dogs [13], [30]. Cystic hydatidosis is endemic in Libya as the stray dogs have freely access to roam around and are often rewarded with the discarded offal of various animals slaughtered for human consumption and constitute the principal definitive host reservoir of disease in the region. The faeces of dogs containing eggs of $\mathrm{E}$. granulosus contaminate environment (ground, grasses and water). Intermediate domestic animal hosts become infected with hydatid cysts when they ingest viable eggs in their food such as vegetables, herbs, fruits or drunk in contaminated water. Due to small size of E. granulosus dogs cay hundreds or even thousands of adult worms without showing any signs of illness to the dogs. The adult worms deposit a large number of eggs which are immediately passed out in the faeces of dogs in the environment. Eggs are immediately source of infection to livestock and humans. The man is considered as 'dead end' host for E. granulosus. The life cycle of the parasite completed when carnivores eat infected herbivores [40], [51].

The life cycle of $\mathrm{E}$. granulosus completes in two mammalian hosts. The first is the definitive host which is usually wild/domestic carnivores for the adult stage of E. granulosus and second is an intermediate host which is usually domestic/wild ungulates for the larval stage (hydatis cyst). In Libya, dogs are the only known natural definitive host of cystic echinococcosis and are responsible for the 
contamination of the pasture with infective eggs [17], [25] and [28].

The present paper is a review on the prevalence of cystic echinococcosis in livestock in Libya. The data were collected from most appropriate publications on this disease.

Livestock Cystic Echinococcosis: Abattoir data on prevalence of cystic hydatidosis from different cities of Libya are presented in the Table. [42] Described first time cystic hydatidosis in domestic animals in Libya and stated that it is common in camels. [15] Reported 40 to $70 \%$ prevalence of cystic echinococcosis disease among sheep and cattle respectively around Tripoli area. Abattoir data collected from Benghazi area eastern of the country from 1975 to 1977 , indicated that the rate of infection of hydatid cyst in imported animals was $0.8 \%$ in sheep, $3.1 \%$ in cattle and $20 \%$ in camels, while in local reared animals the rate of infection of hydatid disease was $2.7 \%$ in sheep, $7.9 \%$ in goats, $11.2 \%$ in cattle and $16 \%$ in camels [24]. [3] Obtained abattoir data in Tripoli area, and found cystic echinococcosis in imported animals were $25.8 \%$ in sheep, $3.8 \%$ in cattle and $26.4 \%$ in camels, while in local reared animals infection rate was $4.3 \%$ in sheep, $6.6 \%$ in cattle and $27.2 \%$ in camels. Later on, [25] collected data from ten slaughter houses around the country and found that, $7.9 \%$ of the infected animals were infected with cystic hydatidosis. [26] Studied hydatid disease in livestock slaughtered in fourteen abattoirs around the country and reported 1.5, 5.4 and 35.9\% among goats, cattle and camels respectively were infected with the disease. Eight years later [28] examined prevalence of cystic echinococcosis in sheep, goats and camels slaughtered in six abattoirs at Zawia, Tripoli, El-Khumes , Misurata, Sirte and Benbhazi abattoirs and found $15.8,3.8$, and $48 \%$ of sheep, goats and camels respectively were infected with hydatid disease. [5] Investigated infection of hydatid cysts in sheep, goats, cattle and camels slaughtered in in the abattoirs from Shahat (Al-Jabal Al- Akhdar) indicated that $8.7 \%$ in sheep, $5.4 \%$ in goats, $6.4 \%$ in cattle and $35 \%$ in camels were infected with cystic hyadtidosis.

Table: Abattoirs data on prevalence of cystic Echinococcosis in livestock from regions.

\begin{tabular}{cccccc}
\hline \multirow{2}{*}{ Locality/City } & \multicolumn{3}{c}{ Infection rate $(\%)$ in livestock } & \multirow{2}{*}{ References } \\
\cline { 2 - 5 } & Sheep & Goat & Cattle & Camel & \\
\hline Benghazi & 3.3 & 18.1 & 13.9 & 29.1 & {$[17]$} \\
Tripoli & 2.7 & 7.9 & 11.2 & 16.1 & {$[24]$} \\
regions & & & & & \\
Tripoli & 25.8 & - & 3.8 & 26.4 & {$[3]$} \\
regions & & 1.5 & 5.4 & 39.5 & {$[26]$} \\
Kufra & - & & & & \\
Shahat (Al- & & & & \\
Jabal Al- & 8.9 & 5.4 & 6.4 & 35.0 & {$[5]$} \\
Akhder) & & & & & \\
Zawia & 15.8 & 3.8 & - & 48.0 & {$[28]$} \\
Benghazi & 20.0 & 3.4 & 13.6 & 11.0 & {$[47]$} \\
Sebha & 18.5 & 4.0 & 15.0 & 12.6 & {$[2]$} \\
Sirte & 4.9 & 2.4 & 2.7 & 15.0 & {$[33]$} \\
Bayada & 56.0 & 40.0 & 28.5 & - & {$[20]$} \\
Misurata & 10.5 & - & 10.5 & 12.5 & {$[35]$} \\
\hline
\end{tabular}

[31] Studied prevalence of hydatid cysts in slaughtered animals in the abattoirs of Benghazi city and reported infection rate of $1 \%$ in sheep, $4.6 \%$ in goats, $1 \%$ in cattle and $2 \%$ in camels. [2] Examined infection of hydatid disease among domestic animals( sheep, goats, cattle and camels) slaughtered for human consumption in the abattoirs, and religious and social occasions in Sebha city and found $18.5 \%$ in sheep, $4 \%$ in goats, $15 \%$ in cattle and $12.6 \%$ in camels were infected with the disease. [47] Examined 1087 sheep, 881 goats, 428 camels and 614 cattle at post mortem in Benghazi abattoirs eastern of the country and found that, 20,3.4, 13.6 and $11 \%$, respectively were infected with Hydatid disease. [32] Examined 1380 local bred camels (Camelus dromedaries) slaughtered at Sirte abattoirs, and found that $3.62 \%$ of the animals were infected with hydatid cysts. One year later, investigation on the prevalence of cystic echinococcosis in livestock was conducted by [21] at Misurata abattoirs about 200Km east of Tripoli the capital; the obtained results showed that, $16.7 \%$ of 6935 sheep, $14.6 \%$ of 1901 cattle and $12.9 \%$ of 1863 camels were infected with hydatid cysts.
[33], published data on hydatidosis in the Sirte abattoirs in sheep, goats, camels and cattle, the data indicated that, 4.9, 2.4, 2.7 and $15 \%$ of these animals respectively were infected with hydatid cysts. Further eastern of the country again, data collected from Bayada city abattoirs (Alkhlele and Atellal) showed that, 56, 40 and $28.5 \%$ of examined sheep (715), goats (500) and cattle (350) respectively were infected with hydatid cyst [20]. One year later, [35] studied incidence of hydatid disease in slaughtered livestock in the city Misurata and reported infection rates of $10.5 \%$ in sheep, in 10.5 $\%$ in cattle and $12.5 \%$ in camels. Lastly, a study by [22], who examined 32,971 livestock animals including 25314 sheep, 7496 camels and 161 cattle from different government abattoirs all around the country, the overall prevalence rate of infection of cystic hydatidosis was $10.0 \%$ and among the individual group of animals, the rate of infection with cystic hydatidosis was $10.5 \%$ in sheep, $12.5 \%$ in camels and $10.5 \%$ in cattle.

Sheep and camels have highest rate of infection than the other animals including cattle and goats and are frequently slaughtered for human consumption in the official abattoirs in the various parts of Libya [17], [24], [31], [47], [33], [35]. A study of [25] may support the idea that sheep/dog strain of E. granulosus is the most common strain in Libya. A comparative study on the biochemical parameters of E. granulosus in hydatid cysts in sheep, goats, cattle and camels suggest the existence of sheep strains of this parasite in different livestock and humans [46].

The infection rate is significantly higher in sheep and maintained endemicity of hydatidosis in the region. In general, goats in Libya always have lower infection of cystic echinococcosis compared to the other intermediate hosts such as sheep, cattle and camels [26], [28] [2] [33]. Two factors may explain this fact, firstly related to the feeding behavior of the goats, where they usually feed on the upper parts or most distal parts of plants and shrubs, while other intermediate hosts feed on the ground grasses which increase the chance of swallowing the eggs of E. granulosus. Secondly related to host immunity [2]. [31] and [35] found none of hydatid cyst was found to be fertile in cattle and probably these animals are unlikely to have significant role in the transmission and maintenance of this parasite. In southern Libya, camels are the main traditional source of meat and are usually slaughtered on religious and social occasions throughout the year. The offal from these animals (liver, lungs and spleen) are usually offered to domestic dogs and cats or dumped in rubbish bins outside houses where stay dogs are easily feed on them. Thus the camels may be playing role to continue the life cycle of $E$. granulosus in the region.

Significant seasonal variations in the prevalence of cystic hydatidosis were also recorded through Libyan abattoir meat inspection and this could be due to the differences in the environmental conditions between the different areas of the country along the different seasons [22] and these findings agreed to those reported in other countries [6], [29]. In addition, other environmental factors such as high altitudes and increasing annual rainfall are also associated with the variable rates of the prevalence of Cystic Echinococcosis in livestock [4] [23]. Moreover, exposing of the parasite eggs to hostile environmental conditions will reduce their infective capacity [47].

In Libya, human behavior play an important role in the increasing risk of infection with cystic hydtidosis to livestock such as feeding of hydatid infected organs to dogs especially in socio-cultural occasions such as the festival of marriage and the religious day (EID Al-UDHA). During these occasions, hundreds of thousands of animals may be slaughtered in a single day under no veterinary inspection which therefore, maintains a highly infected dog population, the majority of which are farm and strays. In addition, lack of anti-helminthic treatment for infected dogs and dog owners' poor health education are all factors influencing the transmissions of hydatid disease between the definitive and intermediate hosts. However, general lack of people knowledge and awareness about infection factors may facilitate the transmission of hydatidosis in Livestock and the epidemiological models such as number and age of hosts, geographical location, species of hosts and the farming management type can identify them, [43]

The levels of infection, particularly with E. granulosus hydatid 
cysts, impose an enormous medical, social and economic burden in the affected areas. Losses due to hydatid disease are largely economic through damage to domestic animals with the possible bans of import and export animals and their products especially from endemic areas [8], [44]. For instance, previous reports from the abattoirs around the country showed high rates of infection with cystic hydatidosis in slaughtered animals, however, such a situation has a critical economic impact due to the disease causing not only losses of internal animal organs and other products such as milk and meat, but also productivity in general [34].

Estimates of economic losses as a result of destroying the infected organs or the whole animal carcasses due to hydatid cysts in Libya are not known because of the unavailability of governmental and abattoir records, however, the high level of infection with Cystic Echinococcosis reported in livestock along the last few decades indicate the possible higher economic losses which may reach hundreds of thousands of Libyan dinars annually [17], [33], [42].

The reported differences in the rate of prevalence of cystic hydatidosis between the different areas and also between the different intermediate hosts could be due to the differences in the environmental factors effecting the parasite eggs, such as temperature, humidity and the nature of the pasture between those areas as well as the existence of different strains of E. granulosus morphologically and biochemically adapted to each farm species [42].

Cystic hydatidosis is prevalent in domestic animals with the variable rates of infection between animal species and between different areas in Libya. The disease remains endemic and enzootic and an increasing public health problem in region because there is no active surveillance and control measures on national and regional levels. The ministries of health, the veterinary services, the civic bodies and law enforcement agencies should play important role for the awareness of hydatid disease and control programs. Provision of facilities for proper disposal of infected offal of animals should be adopted and should not be dumped nearby human residences and in the nearby desert as each of these sites has its own dog populations, which have free access in the transmission of hydatid disease in the regions. In Libya, unregulated private slaughter of livestock is universal in both rural and urban areas, almost on every marriage, birth of child and even acquisition of a new house or a car is an occasion for animal sacrifice. People should be educated to avoid offering offal of slaughtered animals to stray dogs. Authorities should obtain regularly abattoir records on the infection of cystic echinococcosis in livestock and, government should provide better supervised abattoirs in the municipalities of the areas.

\section{References:}

[1]- Abdul-Hafeez, S. K. and Kamhavi, S. A. (1993): Cystic echinococcosis in Jordan. Echinomed, 9: 5.

[2]- Abobaker, A. M. (2004): Prevalence and epidemiology of hydatidosis in Sebha city. M.Sc. Thesis, Faculty of Science.

[3]- Aboudaya, M. A. (1985): Prevalence of Echinococcus granulosus among domestic animals in Libya. Trop. Anim. Health Prod., 17: 169-70. DOI: 10.1007/BF02355879.

[4]- Acosta-Jamett, G., Cleavel, S., Cunningham, A. A., Bronsvoort, B.M.C. and Craig, P.S. (2010): Echinococcus granulosus infection in humans and livestock in the Coquimbo region, north-central Chile. Vet. Parasitol., 169: 102-110. DOI: 10.1016/j.vetpar.2009.12.009.

[5]- Al-Khalidi, N.W. (1998): Cystic echinococcosis (hydatidosis) in sheep, goats, cattle and camels in Shahat abattoir, Al-Jabal, Libya. Proceedings of the 3rd Annual Meeting for Animal Production under Arid Conditions, (UAC; 98), United Arab Emirates University, pp: 143-149.

[6]- Ansari-Lari, M. (2005): A retrospective survey of hydatidosis in livestock in Shiraz, Iran, based on abattoir data during 19992004. Vet. Parasitol., 133: 119-123. DOI: 10.1016/j.vetpar.2005.05.031.

[7]- Araujo, F.P., Schwabe, C.W., Sawyer, J.C. and Davis, W.G. (1975): Hydatid disease transmission in California. Am. J. Epidemiol, 102: 291-302. [PubMed] [Google Scholar].
[8]- Battelli, G. (2009): Echinococcosis: Costs, losses and social consequences of a neglected zoonosis. Vet. Res. Commun., 33: 47-52. DOI: 10.1007/s11259-009-9247-y.

[9]- Bowels, J., Blair, D. and McManus, D. P. (1992): Genetic variants within the genus Echinococcus identified by mitochondrial sequencing. Mol. Biochem. Parasitol. 54: 165174.

[10]- Bowels, J. and McManus, D. P. (1993a): Rapid discrimination of Echinococcus species and strains using a PCR-based RFLP method. Mol. Biochem. Parasitol. 57: 231-239.

[11]- Bowels, J. and McManus, D. P. (1993b): Molecular variation in Echinococcus. Acta.Tropica. 53:291-305. 3-4.

[12]- Dunn, F.L. (1979): Behavioral aspects of the control of parasitic diseases. Bulletin of the World Health Organization 57 499-512. [PMC free article] [PubMed] [Google Scholar]

[13]- Buishi, I., Walters, T., Guildea, Z., Craig, P. and Palmer, S.R. (2005): Reemergence of Canine Echinococcus granulosus Infection, Wales. Emer. Infect. Dis. 11: 568-571. [PMC free article] [PubMed] [Google Scholar]

[14]- Buishi, I., Njoroge, E., Zeyhle, E., Rogan, M.T. and Craig P.S. (2006): Canine echinococcosis in Turkana (north-western Kenya): a coproantigen survey in the previous hydatid-control area and an analysis of risk factors. Ann Trop Med Parasitol 100: 601-610. [PubMed] [Google Scholar]

[15]- Cicogna, D. (1961): Eechinociccosi in Tripolitania. Boll. San. Del. Trip., 2.

[16]- Dar, F. K. and Al-Karmi, T. (1997): Public health aspect of cystic echinococcosis in the Arab countries. Acta Tropica; 67: 125-132.

[17]- Dar, F.K. and Taguri, S.C. (1979): Epidemiology and Epizootiology Hydatidosis in the Libya Jamahiriya and Recommendations for a Programmer of Surveillance and Control of the Disease. Garyounis Medical Journal, 2: 11-15.33.

[18]- Dunn, F.L. (1979): Behavioral aspects of the control of parasitic diseases. Bulletin of the World Health Organization 57: 499-512. [PMC free article] [PubMed] [Google Scholar]

[19]- Eckert, J., Thompson, R.C. A., Michael, S. A., Kumaratilake, L. M. and El Sawah, H. M. (1989): Echinococcus granulosus of camelorigin; development in dogsand parasite morphology. Parasitol. Res; 75: 536-542.

[20]- Ekhnefer, A.M.H. (2014): Prevalence of cystic echinococcosis infestation sheep, goats and cattle in the Bayda city- Libya. Am. J. Res. Comm., 2: 11-22.

[21]- Elmajdoub, L.O.M., El-Hoti, K.M. and Hadid, N.M. (2007): Prevalence of hydatid disease in slaughtered livestock animals from Misurata abattoir- Libya. J. Uni. Arab Bio. , 28A: 163-174.

[22]- Elmajdoub, L.O.M. and Rahman, W. A. (2015): Prevalence of hydatid cysts in slaughtered animals from different areas of Libya. Open J. Vet. Med., 5: 1-10.DOI: 10.4236/ojvm.2015.51001.

[23]- Fromsa, A. and Jobre, Y. (2011): Infection prevalence of hydatidosis (Echinococcus granulosus, Batsch, 1786) in domestic animals I $n$ Ethiopia: A synthesis report of previous surveys. Eth. Vet. J., 15: 11-33. DOI: 10.4314/evj.v15i2.67691.

[24]- Gebreel, A. O., Gilles, H. M. and Prescott, J. E. (1983): Studies on the sero-epidemiology of endemic diseases in Libya. I. Echinococcosis in Libya. Ann. Trop. Med. Parasitol., 77: 391 397. PMID: 6.

[25]- Gusbi, A.M., Awan, M.A. and Beesley, W.N. (1987): Echinococcosis in Libya. II. Prevalence of hydatidosis (Echinococcus granulosus) in sheep. Ann. Trop. Med. Parasitol., 81: 35-41. PMID: 3675041

[26]- Gusbi, A.M., Awan, M.A.Q. and Beesley, W.N. (1990): Echinococcosis in Libya. IV. Prevalence of hydatidosis (Echinococcus granulosus) in goats, cattle and camels. Ann. Trop. Med. Parasitol., 84: 477-82. PMID: 2256770639185.

[27]- Hope, M., Bowels, J. and McManus, D. P. (1991): A reconsideration of the Echinococcus granulosus strain situation in Australia following RFLP analysis of cystic materials. Int. J. Parasitol., 21:471-475. 
[28]- Ibrahem, M.M. and Craig, P.S. (1998): Prevalence of cystic echinococcosis in camels (Camelus dromedarius) in Libya. J. Helminth., 72: 27-31. DOI: 10.1017/S0022149X00000936.

[29]- Ibrahim, M. (2010): Study of cystic echinococcosis in Slaughtered animals in Al Baha region, Saudi Arabia: Interaction between some biotic and abiotic factors. Act. Trop., 113: 26-33. DOI: 10.1016/j.actatropica.2009.08.029.

[30]- Inangolet, F., Biffa, D., Opuda-Asibo, J., Oloya, J. and Skjerve, E. (2010): Distribution and intensity of Echinococcus granulosus infections in dogs in Moroto District, Uganda. Trop. Anim. Health. Prod. 42: 1451-1457. [PubMed] [Google Scholar]

[31]- Khan, A. H. and El-Buni, A. A. (1999); Prevalence of Hydatid cysts in slaughtered animals in Benghazi, Sebha Med. J., 2:7-9.

[32]- Kassem, A.H. and Gdoura, N.K. (2006): Hydatidosis in camels (Camelus dromedarius) slaughtered at Sirt abattoir, Libya. J. Egypt. Soc. Parasitol., 36: 1-10. PMID: 17366866.

[33]- Kassem, A.H., A. Abdul-kader and S.A. Nass (2013): Prevalence of hydatid cysts in slaughtered animals in Sirte, Libya. J. Egypt. Soc. Parasitol., 43: 33-40. DOI: $10.12816 / 0006365$.

[34]- Lahmar, S., Kilani, M., Torgerson, P.R. and Gemmell, M.A. (1999): Echinococcus granulosus larvae in the livers of sheep in Tunisia: The effects of host age. Ann. Trop. Med. Parasitol., 93: 75-81.DOI: 10.1080/00034989958825.

[35]- Layla, O. E., and Wahab, A. R. (2015): Prevalence of Hydatid Cysts in Slaughtered Animals from Different Areas of Libya, Journal of Veterinary Medicine, 5, 1-10

[36]- Lymbery, S. M., Thompson, R. C. A. and Hobbs, R. P. (1990): Genetic diversity and genetic differentiation in Echinococcus granulosus (Batsch, 1786) from domestic and sylvatic hosts on the main land of Australia. Parasitol., 101: 283-289.

[37]- Mastin, A., Brouwer, A., Fox, M., Craig, P., Guitián, J. et al. (2011): Spatial and temporal investigation of Echinococcus granulosus coproantigen prevalence in farm dogs in South Powys, Wales. Vet.Parasitol. 178: 100-107. [PubMed] [Google Scholar]

[38]- McManus, D. P., simpson, A. G. J. and Rishi, A. K. (1987): Characterization of the hydatid disease organism Echinococcus granulosus from Kenya, using cloned DNA markers. Pp.29-36in Geerts, S. Kumar, V. and Brandt, J. (Eds)., Hel. Zoon. Dordrecht, Nijhoff.

[39]- McManus, D. P. and Rishi, A.K. (1989): Genetic heterogeneity within Echinococcus granulosus: isolates from different hosts and geographical areas characterized with DNA probe. Parasitol ,78: 193-198.

[40]- McManus, D.P., Zhang, W., Li, J. and Bartley, P.B. (2003): Echinococcosis. Lancet, 362: 1295-1304.DOI: 10.1016/S01406736(03)14573-4.

[41]- Macpherson, C.N.L. (2005): Human behavior and the epidemiology of parasitic zoonoses. Int. J. Parasitol, 35: 13191331. [PubMed] [Google Scholar].

[42]- Medulla, C. (1931): La Cirenaica del punto di vista Sanitario. Arch. Ital. Sci. Med. Colo., 12: 391-418.

[43]- Mohamed M. I., Wafa M. I., Mostafa M. A. and Kawther M. I. (2016): Livestock hydatid disease (cystic hydtaidosis) in Libya: A review. Am. J. Ani. Vet. Sci, 11: 70-84.

[44]- Otero-Abad and Torgerson, P. R. (2013): A systemic review of the epidemiology of Echinococcosis in domestic and wild animals. PLoS Negl. Trop. Dis, 7: e2249. doi: 10.1371/journal.pntd.0002249.

[45]- Sariozkan, S. and Yalcin, C. (2009): Estimating the production losses due to cystic echinococcosis in ruminants in Turkey. Vet. Parasitol., 163: 330-334. DOI: 10.1016/j.vetpar.2.

[46]- Shaafie, I. A., Khan, A .H. and Rambabu, K. (1999): Biochemical profiles of hydatid cyst fluids of Echinococcus granulosus of human and animal origin in Libya. J. Helminthol., 73:255-258.

[47]- Tashani, O.A., Zhang, L.H. Boufana, B., Jegi, A. and McManus, D.P. (2002): Epidemiology and strain characteristics of Echinococcus granulosus in the Benghazi area of eastern Libya. Ann. Trop. Med. Parasitol., 96: 369-381. DOI: 10.1179/000349802125000952.
[48]- Torgerson, P.R., Williams, D.H. and Abo-Shehada, M.N. (1998): Modeling the prevalence of Echinococcus and Taenia species in small ruminants of different ages in northern Jordan. Vet. Parasitol., 79: 35-51.DOI: 10.1016/S0304-4017(98)001575 .

[49]- Wachira, T. M., Bowels, J., Zeyhle, E. and McManus, D. P. (1993): Molecular estimation of sympatry and distribution of sheep and camel strains of Echinococcus granulosus in Kenya. Am. J. Trop. Med. Hyg., 48: 473-479.

[50]- Yang, Y.R., Rosenzvit, M.C., Zhang, L.H., Zhang, J.Z. and McManus, D. P. (2005): Molecular Study of Echinococcus in West-Central China. Parasitol, 131: 547-555. http://dx.doi.org/10.1017/S0031182005007973.

[51]- Zhang, W., Li, J. and McManus, D.P. (2003): Concepts in immunology and diagnosis of hydatid disease. Clin. Microb. Rev., $\quad 16: \quad 18-36 . \quad$ DOI: $10.1128 /$ CMR.16.1.1836.2003009.04.032. 